\title{
Analisis Perbandingan Pembiayaan Bank Syariah dan Kredit Bank Konvensional Terhadap Peningkatan Pendapatan Ekonomi Kreatif (Studi Kasus Pada UMKM di Kota Jambi)
}

\author{
Rita Friyani \\ Dosen Fakultas Ekonomi dan Bisnis Universitas Jambi \\ Email: ritafriyani@yahoo.co.id
}

\begin{abstract}
ABSTRAK
Penelitian ini bertujuan untuk memperoleh hasil perbandingan antara pembiayaan oleh Bank Syariah dan Kredit oleh Bank Konvensional terhadap pendapatan UMKM Kota Jambi. Dana yang diperoleh oleh UMKM apakah mampu meningkatkan pendapatan dan pengembangan serta apakah UMKM mampu mengembalikan dana yang telah dikucurkan. Penelitian ini diharapkan mampu memperoleh hasil yang bermanfaat untuk UMKM dan perbankan. Bagi UMKM untuk dapat membandingkan pemberian kredit manakah yang lebih menguntungkan sedangkan bagi Perbankan sebagai bahan pembanding antara kredit perbankan konvensioanl dan pembiayaan musyarakah perbankan syariah. Penelitian ini berupa penelitian kualitatif yang menggambarkan dampak pembiayaan dan kredit terhadap UMKM. Data yang digunakan berupa data primer berupa wawancara dan data sekunder yang diperoleh dari perbankan yang bersangkutan. Selain data dari perbankan juga akan diperoleh data dari UMKM dengan interview dan laporan pendapatan. Hasil penelitian ini dapat digunakan baik untuk kepentingan akademisi maupun praktisi. Akademisi dapat digunakan untuk penelitian dan bahan perkuliahan. Praktisi dapat menjadi bahan pertimbangan pemberian pembiayaan dan atau kredit.
\end{abstract}

Kata Kunci : Pembiayaan, Kredit, Syariah, Konvensional, UMKM

\section{PENDAHULUAN}

\section{Latar Belakang}

Usaha mikro kecil dan menengah atau sering disebut dengan UMKM menurut UU No. 20 Tahun 2008 adalah : Pertama, usaha mikro adalah usaha produktif milik orang-perorangan dan atau badan usaha perorangan yang memiliki kriteria usaha mikro sebagaimana diatur dalam undang-undang. Kedua, usaha kecil adalah usaha produktif yang berdiri sendiri dan dilakukan oleh orang-perorangan atau badan usaha yang bukan merupakan anak perusahaan atau bukan cabang perusahaan yang dimiliki, dikuasai, atau menjadi bagian langsung atau tidak langsung dari usaha menengah atau usaha besaryang memenuhi kriteria usaha kecil. Ketiga, usaha menengah adalah usaha ekonomi produktif yang berdiri sendiri dan dilakukan oleh orang-perorangan atau badan usaha yang bukan merupakan anak perusahaan atau cabang perusahaan yang dimiliki, dikuasi, atau menjadi bagian baik langsung maupun tidak langsung dengan usaha kecil atau besar dengan jumlah kekayaan bersih atau hasil penjualan tahunan. . Pada tahun 2016 dikutip dari Tempo, Gubernur Bank Indonesia mengatakan bahwa UMKM pada tahun 2016 berkontribusi sebesar 60,3\% atas PDB Indonesia, dan ditargetkan akan naik hingga 70\%. UMKM merupakan salah satu sektor perekonomian yang mampu bertahan dan menyelamatkan perekonomian Indonesia pada saat krisis ekonomi, hal ini terbukti pada saat 
krisis ekonomi tahun 1997. UMKM tetap bertahan sedangkan usaha-usaha besar banyak yang berjatuhan. Kemampuan UMKM bertahan dimasa krisis ekonomi sepatutnya UMKM dikatakan sebagai tulang punggung perekenomian Indonesia. Tiga faktor peran penting UMKM dalam perekenomian (BI, 2009), pertama: jumlah UMKM banyak dan ada dalam setiap sektor ekonomi. Data BPJS tahun 2007 mencatat bahwa 99\% total usaha di Indonesia adalah berasal dari UMKM. Kedua, UMKM mempunyai potensi besar dalam penyerapan tenaga kerja. Sektor UMKM menyerap 97,3\% dari total angkatan kerja yang bekerja. Ketiga, UMKM memberikan kontribusi yang besar terhadap pendapatan nasional.

Dalam perspektif dunia, sudah diakui bahwa usaha Mikro kecil dan menengah (UMKM) sejak lama telah memainkan suatu peran vital di dalam pembangunan dan pertumbuhan ekonomi. Peran tersebut tidak hanya dirasakan oleh negara-negara sedang berkembang tetapi juga di negara-negara maju.

Di negara maju, UMKM sangat penting tidak saja karena kelompok usaha tersebut menyerap paling banyak tenaga kerja tetapi juga dikarenakan kontribusinya terhadap pembentukan atau pertumbuhan produk domestik bruto (PDB) paling besar dibandingkan dengan kontribusi dari usaha besar. Piper (1997) menyatakan bahwa sebanyak 12 juta orang atau sekitar 63,2 persen dari jumlah tenaga kerja di Amerika Serikat (AS) bekerja di 350.000 perusahaan. Rata-rata setiap perusahaan memperkerjakan tidak kurang dari 500 orang. Di Amerika Serikat, perusahaan- perusahaan seperti itu dikategorikan sebagai UMKM. Menurut Aharoni (1994), jumlah UMKM adalah sekitar 99\% dari jumlah unit usaha di negara adidaya tersebut. Perusahaan-perusahaan tersebut merupakan inti dari basis industri di AS (Piper, 1997).

UMKM mulanya tidak dilirik oleh perbankan untuk diberikan pinjaman, akan tetapi setelah krisis ekonomi terjadi sebaliknya, UMKM telah menjadi salah satu pasar bagi perbankan untuk diberikan pinjaman. UMKM memiliki keunggulan mampu bertahan dalam keadaan krisis ekonomi bukan berarti tidak memiliki kelemahan. Anoraga et all (2002), salah satu kelemahan UMKM masih lemahnya perkembangan dan penguatan usaha. Orangperorangan yang memilih melakukan usaha, pada tahap awal mampu mencukupi modal dalam menjalankan aktivitas usahanya. Seiring dengan majunya usaha yang dilakukan maka usaha tersebut harus selalu dilakukan inovasi dan butuh perkembangan usaha. Mengembangkan usaha berarti membutuhkan modal tambahan. Keterbatasan pemilik modal untuk mengembangkan usaha menjadi salah satu faktor yang menyulitkan perkembangan usaha.

Secara umum, peran strategis UMKM juga dapat dilihat di Indonesia. Peran tersebut terlihat dari kontribusinya terhadap Produk Domestik Bruto (PDB) Indonesia yang terus meningkat setiap tahun. Berdasarkan hasil survei dan perhitungan Badan Pusat Statistik (BPS, 2008), kontribusi UMKM terhadap PDB (tanpa migas). Pada Tahun 2007 tercatat sebesar 62,71 persen dan pada Tahun 2008 kontribusinya meningkat menjadi 64,47 persen.

Usaha Mikro Kecil Menengah (UMKM) di Indonesia merupakan salah satu soko guru perekonomian Indonesia selain koperasi. Hal ini dapat terlihat dari bukti nyata bahwa sebagian besar UMKM di Indonesia tidak menghadapi krisis di tengah-tengah krisis global pada tahun 2008 lalu. Perkembangan jumlah UMKM dari tahun ke tahun semakin bertambah. Pada akhir tahun 2008 pangsa pasar kredit MKM mencapai 49,5\%dari total kredit perbankan 
(BI, 2009). Besarnya pangsa kredit MKM tersebut terlihat bahwa perbankan memandang UMKM sebagai unit usaha yang layak dibiayai dan menguntungkan secara komersial. Keterbatasan modal yang dimiliki oleh pemilik usaha sehingga membutuhkan bantuan dari pihak lain. Pihak yang paling dilirik adalah lembaga keuangan terutama lembaga perbankan. Lembaga perbankan baik yang konvensional maupun yang berbasis syariah. Lembaga perbankan konvensional dikenal dengan sebutan kredit sedangkan perbankan syariah disebut dengan pembiayaan.

Tabel 1. Kredit Debit UMKM Provinsi Jambi

\begin{tabular}{cc}
\hline Tahun & Debit/kredit UMKM (Milyar Rupiah) \\
\hline 2012 & 8.002 \\
2013 & 8.950 \\
2014 & 10.499 \\
2015 & 11.730 \\
2016 & 12.188 \\
\hline
\end{tabular}

Sumber: Bank Indonesia

Dari tabel diatas yang diambil dari data Bank Indonesia, terlihat bahwa kredit/debit UMKM Provinsi jambi selalu mengalami kenaikan. Hal ini berarti UMKM semakin besar ketergantungan akan dunia perbankan. Hal ini mengindikasikan bahwa semakin banyaknya jumlah UMKM di jambi dan juga semakin banyaknya UMKM yang membutuhkan modal untuk keperluan usaha. Hal ini menarik perhatian adanya kemungkinan dengan keberhasilan UMKM akan menimbulkan niat dan minat untuk warga lain yang ingin berusaha di bidang UMKM. Secara umum, khususnya dalam aspek finansial, hanya sedikit UMKM yang mengalami perkembangan dalam hal kinerja keuangannya. Hal ini tak lepas dari terbatasnya modal yang dimiliki oleh pelaku UMKM. Keterbatasan modal itu sendiri sebenarnya bisa diatasi dengan mengajukan pinjaman kredit modal kerja atau pembiayaan baik di Bank konvensional maupun bank syariah. Maraknya jenis pembiayaan yang ditawarkan baik dari bank syariah maupun konvensional membuat pelaku UMKM harus mempertimbangkan secara jelas kelebihan dan kekurangan masing-masing jenis pembiayaan.

Dari latar belakang tersebut, peneliti tertarik untuk melakukan penelitian mengenai "analisis perbandingan pembiayaan bank syariah dan kredit bank konvensional terhadap peningkatan pendapatan ekonomi kreatif (studi kasus pada umkm di kota jambi)"

\section{Perumusan Masalah}

Berdasarkan uraian latar belakang masalah penelitian di atas, maka rumusan masalah dalam penelitian ini adalah :

1. Bagaimanakah Pembiayaan di Bank Syariah bagi Peningkatan Pendapatan Ekonomi Kreatif

2. Bagaimanakah Kredit Bank Konvensional bagi Peningkatan Pendapatan Ekonomi Kreatif

3. Bagaimanakah perbandingan pembiayaan bank syariah dan kredit bank konvensional bagi Peningkatan Pendapatan Ekonomi Kreatif. 


\section{Tujuan dan manfaat penelitian}

\section{Tujuan Penelitian}

Adapun tujuan penelitian ini adalah :

1. Untuk mengetahui bagaimanakah Pembiayaan di Bank Syariah bagi Peningkatan Pendapatan Ekonomi Kreatif

2. Untuk mengetahui bagaimanakah Kredit Bank Konvensional bagi Peningkatan Pendapatan Ekonomi Kreatif

3. Untuk mengetahui perbandingan pembiayaan bank syariah dan kredit bank konvensional bagi Peningkatan Pendapatan Ekonomi Kreatif

\section{Manfaat Penelitian}

Manfaat dari penelitian ini adalah:

1. Memberikan pengetahuan dan wawasan mengenai Pembiayaan di Bank Syariah bagi Peningkatan Pendapatan Ekonomi Kreatif

2. Memberikan pengetahuan dan wawasan mengenai Kredit Bank Konvensional bagi Peningkatan Pendapatan Ekonomi Kreatif.

3. Memberikan pengetahuan dan wawasan mengenai perbandingan pembiayaan bank syariah dan kredit bank konvensional bagi Peningkatan Pendapatan Ekonomi Kreatif

\section{Variabel Penelitian}

\section{METODE PENELITIAN}

Variabel penelitian terdiri dari variabel dependen dan variabel independen. Variabel independen adalah Pembiayaan Bank Syariah dan Kredit Bank Konvensional sedangkan variabel dependennya adalah Peningkatan Pendapatan.

\section{Prosedur Penelitian}

Populasi penelitian ini adalah Bank Syariah dan Bank Konvensional di Kota Jambi. Sampel penelitian ini adalah 1 Bank Syariah dalam hal ini disebut Bank X dan 1 bank konvensional dalam hal ini disebut Bank Y. Data yang dikumpulkan berupa data primer yang akan diperoleh dari penyebaran kuesioner dan wawancara. Nama Bank hanya inisial berdasarkan permintaan pihak perbankan. Analisis yang dilakukan adalah perbandingan

\section{Subjek Penelitian}

Subjek penelitian adalah pemberian pembiayaan (musyarakah) di bank syariah dan pemberian kredit di bank konvensional.

\section{HASIL DAN PEMBAHASAN}

\section{Hasil Penelitian}

Analisis yang dilakukan dalam penelitian ini adalah Analisis Perbandingan. Dimulai dari melakukan analisis mengenai pembiayaan di bank syariah dan dampaknya terhadap peningkatan pendapatan ekonomi kreatif. Kemudian analisis mengenai kredit di bank konvensional dan dampaknya terhadap peningkatan pendapatan ekonomi kreatif. Setelah itu barulah dilakukan analisis perbandingan antara pembiayaan di bank syariah dan kredit di bank konvensional terhadap peningkatan pendapatan ekonomi kreatif. Langkah terakhir 
dilakukan analisis mengenai kelebihan dan kekurangan masing-masing jenis pembiayaan dan kredit tersebut.

\section{Pembiayaan (Musyarakah) di Bank Syariah bagi Peningkatan Pendapatan Ekonomi Kreatif}

Pengertian pembiayaan (musyarakah) menurut UU No. 10 tahun 1998 yaitu penyediaan uang/tagihan yang dapat dipersamakan dengan itu berdasarkan persetujuan atau kesepakatan antara bank dengan pihak lain yang mewajibkan pihak yang dibiayai untuk mengembalikan uang atau tagihan tersebut setelah jangka waktu tertentu dengan imbalan atau bagi hasil.

Prosedur/langkah-langkah pemberian pembiayaan musyarakah di bank syariah X untuk UMKM adalah sama dengan prosedur pemberian pembiayaan lainnya yaitu sebagai berikut :

* Permohonan oleh pihak UMKM

* Diterima untuk diproses di Account Officer

* Di survey, jika ditolak dilanjutkan laporan tolakan dan disampaikan kepada pihak UMKM. Jika diterima lanjut ke pengusulan oleh Account Officer kemudian lanjut ke proses berikutnya

* Pembahasan

* Disetujui oleh pimpinan

* Pencairan

Total jumlah pembiayaan musyarakah di Bank Syariah X untuk tahun XXX adalah sebesar Rp. 93.000.000.000 dengan rata-rata pinjaman mulai dari Rp. 2.000.000 sampai dengan Rp. 100.000.000.

\section{Kredit di Bank Konvensional bagi Peningkatan Pendapatan Ekonomi Kreatif}

Pengertian Kredit menurut UU RI No. 10 tahun 1998 yaitu penyediaan uang atau tagihan yang dapat dipersamakan dengan itu berdasarkan persetujuan atau kesepatan pinjam meminjam antara bank dengan pihak lain yang mewajibkan pihak peminjam melunasi utangnya setelah jangka waktu tertentu dengan pemberian bunga.

Prosedur/langkah-langkah pemberian kredit pada bank konvensional Y untuk UMKM adalah sama dengan prosedur pemberian kredit pada umumnya yaitu sebagai berikut :

- Permohonan oleh pihak UMKM

- Diterima untuk diproses oleh Account officer

- Disurvey, jika ditolak dibuat laporan penolakan dan disampaikan ke pihak UMKM. Jika diterima lanjut ke pengusulan oleh Account Officer kemudian ke tahap selanjutnya

- Pembahasan komite

- Disetujui oleh Pimpinan

- Pencairan

Total jumlah kredit yang disalurkan oleh bank konvensional Y untuk tahun XXX adalah sebesar Rp. 224.300.000.000 dengan tingkat suka bunga kredit sebesar 8,74\%.

\section{Perbandingan Pembiayaan di Bank Syariah dan Kredit di Bank Konvensional}

Istilah kredit di bank konvensional sama dengan pembiayaan (musyarakah) di bank syariah. Namun prakteknya, kredit dan pembiayaan memiliki perbedaan. Adapun perbedaan tersebut dapat dilihat pada tabel berikut ini : 
Tabel 2. Perbedaan Kredit Pada Bank Konvensional Dengan Pembiayaan (Musyarakah) Pada Bank Syariah

\begin{tabular}{lll}
\hline \multicolumn{2}{c}{ Kredit } & \multicolumn{2}{c}{ Pembiayaan (Musyarakah) } \\
\hline 1. Memakai perangkat bunga & $\begin{array}{l}\text { 1. Berdasarkan bagi hasil } \\
\text { 2. Hubungan dengan nasabah sebagai } \\
\text { debitur-kreditur }\end{array}$ & $\begin{array}{l}\text { 2. Hubungan dengan nasabah dalam } \\
\text { bentuk kemitraan }\end{array}$ \\
3. Investasinya bisa halal, subhat dan & $\begin{array}{l}\text { 3. Melakukan investasi yang halal saja } \\
\text { haram }\end{array}$ & $\begin{array}{l}\text { 4. Berorientasi keuntungan duniawi dan } \\
\text { akhirat }\end{array}$ \\
\hline
\end{tabular}

Dari tabel tersebut di atas, jelas terlihat perbedaan mendasar antara kredit di bank konvensional dengan pembiayaan (musyarakah) di bank syariah. Selanjutnya perbedaan yang mendasar antara kredit bank konvensional dengan pembiayaan bank syariah adalah bunga dan bagi hasil. Menurut Syafi'i Antonio (2007:61) perbedaan bunga dan bagi hasil dapat dijelaskan dalam tabel berikut ini :

\section{Tabel 3. Perbedaan Bunga dan Bagi Hasil}

\section{Bunga Bagi Hasil}

- Penentuan bunga dibuat pada waktu akad dengan asumsi harus selalu untung

- Penentuan rasio/nisba bagi hasil dibuat pada waktu akad dengan berpedoman pada kemungkinan untung rugi

- Besarnya presentase berdasarkan pada jumlah uang (modal) yang dipinjamkan

- Besarnya rasio hasil berdasarkan jumlah keuntungan yang diperoleh

- Pembayaran bunga tetap seperti yang dijanjikan tanpa pertimbangan apakah proyek yang dijalankan oleh pihak nasibah untung atau rugi

- Bagi hasil bergantung pada keuntungan proyek yang dijalankan. Bila usaha merugi, kerugian akan ditanggung bersama oleh kedua belah pihak

- Jumlah pembayaran bunga tidak meningkat sekalipun jumlah keuntungan berlipat

- Eksistensi bunga diragukan oleh semua agama

- Jumlah pembagian laba meningkat sesuai dengan peningkatan jumlah pendapatan

- Tidak ada yang meragukan bagi hasil

Setelah dilakukan analisis perbandingan pembiayaan di bank syariah $\mathrm{X}$ dan kredit di bank konvensional $\mathrm{Y}$ di kota jambi, terdapat persamaan dan perbedaan pemberian kredit dan pembiayaan tersebut.

\section{Persamaan Pemberian Pembiayaan (Musyarakah) dan Kredit}

Persamaan dari pemberian pembiayaan (musyarakah) pada Bank X dengan pemberian kredit pada Bank Y Kota Jambi adalah terletak pada prosedur-prosedur yang dilakukan, dimulai dari proses pengajuan hingga monitoring. Persamaan yang lainnya yaitu pada saat melakukan analisa rasio. Persamaan-persamaan tersebut dapat diuraikan sebagai berikut : 
- Persamaan Prosedur

Dalam memberikan kredit atau pembiayaan tentunya bank memiliki prosedurprosedur yang harus dilaksanakan calon debitur baik pada Bank syariah Y maupun bank konvensional Y. Prosedur-prosedur tersebut antara lain :

a. Proses pengajuan pembiayaan musyarakah atau pengajuan kredit

b. Pengumpulan data dan persyaratan

c. Analisa kredit atau pembiayaan dan analisa rasio

d. Keputusan kredit atau pembiayaan musyarakah

e. Pengikatan

f. Monitoring

- Persamaan Analisa Rasio

Meskipun analisa rasio bukanlah alat utama penentu besar kecilnya pencairan kredit atau pembiayaan musyarakah, tetapi analisa rasio penting dilakukan untuk memelihara kondisi keuangan perusahaan.

\section{Perbedaan Pemberian Pembiayaan Musyarakah dan Pemberian Kredit}

Selain persamaan juga terdapat perbedaan mendasar pada pemberian pembiayaan musyarakah bank syariah X dan pemberian kredit Bank Y. Perbedaan tersebut antara lain

- Metode atau Dasar dalam menentukan besarnya pencairan kredit.

Metode atau dasar dalam menentukan besarnya pencaiaran kredit yaitu di Bank Syariah X menggunakan analisa proyeksi keuangan sebagai dasar persetujuan besarnya pencairan pembiayaan musyarakah. Analisa proyeksi arus kas ini harus dibuat untuk setiap permohonan pembiayaan, proyeksi arus kas dibuat untuk menilai kebutuhan keuangan debitur dalam hal ini UMKM (jumlah, kapan digunakan dan berapa lama) dan untuk menilai kemampuan debitur (UMKM) untuk menilai kemampuan dalam membayar kembali hutangnya kepada bank.

- Keuntungan Yang Diperoleh.

Sebenarnya terdapat perbedaan yang nyata, yakni pada keuntungan yang diperoleh dari pemberian pembiayaan musyarakah dan pemberian kredit tersebut. Di bank konvensional Y keuntungan yang diperoleh didapatkan dari perolehan bunga kredit. Sedangkan di bank syariah $\mathrm{X}$ keuntungan diperoleh dari sistem bagi hasil.

Setelah dilakukan analisis perbandingan persamaan dan perbedaan antara Bank Syariah X dan Bank Konvensional $\mathrm{Y}$ terkait dengan pemberian kredit dan pembiayaan musyarakah, kemudian dilanjutkan dengan analisis perbandingan jumlah penyaluran kredit untuk UMKM dan Pembiayaan musyarakah untuk UMKM di Kota Jambi. Untuk lebih jelasnya dapat dilihat pada tabel berikut ini :

Tabel 4. Perbandingan Jumlah Penyaluran Kredit dan Pembiayaan untuk UMKM

\begin{tabular}{lccc}
\hline & & Bank Syariah X & Bank Konvensional Y \\
\hline $\begin{array}{l}\text { Jumlah Kredit UMKM yang } \\
\text { disalurkan }\end{array}$ & 93.000 .000 .000 & 224.300 .000 .000 \\
$\begin{array}{l}\text { Jumlah debitur } \\
\text { disalurkan }\end{array}$ & yang & 2.500 & 11.258 \\
\hline
\end{tabular}


Dari total kredit UMKM di Kota Jambi sebesar Rp. 11,3 Trilyun, di Bank Syariah X jumlah kredit UMKM nya sebesar RP. 93.000.000.000 sedangkan di Bank Konvensional Y sebesar Rp. 224.300.000.000 dengan jumlah debitur UMKM untuk Bank Syariah X sebanyak 2.500 debitur sedangkan di Bank Konvensional Y sebanyak 11.258 debitur.

Dari tabel tersebut dapat terlihat perbedaan yang cukup signifikan pemberikan pembiayaan musyarakat di Bank Syariah X dengan kredit di Bank Konvensional Y. Berdasakan hasil wawancara dengan pihak UMKM dan analisa, penyebab pihak UMKM lebih banyak mengajukan kredit/pembiayaan di bank konvensional Y dikarenakan :

1. Sosialisasi dan iklan berkaitan dengan kredit di Bank Konvensional Y lebih gencar sehingga diketahui masyarakat luas

2. Pemahaman masyarakat yang menganggap pengajuan pembiayaan musyarakah di Bank Syariah X hanya untuk agama tertentu saja dalam hal ini Islam

Sedangkan terkait dengan pemberian kredit/pembiayaan musyarakah terhadap peningkatan pendapatan UMKM pada dasarnya sama. Dari hasil wawancara dan analisa dengan pelaku UMKM, baik itu pembiayaan musyarakah maupun kredit yang diberikan ke UMKM semuanya meningkatan pendapatan UMKM karena dengan tambahan kucuran dana maka pihak UMKM dapat mengembangkan usaha nya secara lebih luas lagi.

\section{a. Luaran Yang Dicapai}

Adapun rencana target capaian luaran dari penelitian ini adalah publikasi ilmiah.

\section{KESIMPULAN DAN SARAN}

\section{Kesimpulan}

Dari Hasil penelitian dapat disimpulkan hal berikut :

1. Pembiayaan musyarakah di Bank Syariah X untuk tahun XXX adalah sebesar Rp. 93.000.000.000 dan diberikan ke 2.500 UMKM

2. Kredit di Bank Konvensional $\mathrm{Y}$ untuk tahun XXX adalah sebesar Rp. 224.300.000.000 diberikan ke 11.258 UMKM dengan tingkat suku bunga 8,74\%

3. Persamaan Bank Syariah $\mathrm{X}$ dan Bank Konvensional $\mathrm{Y}$ untuk pemberian kredit/pembiayaan adalah persamaan prosedur dan analisa rasio. Perbedaan Bank Syariah X dan Bank Konvensional Y untuk pemberian kredit/pembiayaan adalah metode atau dasar penentuan kredit serta perbedaan keuntungan yang diperoleh.

\section{Saran}

1. Bagi pihak Bank Syariah $\mathrm{X}$ agar bisa melakukan sosialisasi dan iklan yang lebih gencar sehingga produk pembiayaan musyarakah dapat diketahui masyarakat luas sehingga pemahaman masyarakat berkaitan dengan pembiayaan musyarakah semakin baik.

2. Bagi pihak Bank Konvensional Y agar semakin meningkatkan jumlah kredit UMKM yang disalurkan agar semakin meningkatkan pendapatan UMKM. 


\section{DAFTAR PUSTAKA}

Anoraga, Panji dan Sudantoko, Djoko. 2002. Kewirausahaan dan Usaha Kecil. Rineka Cipta: Jakarta

Arifin, Zainul. 2009. Dasar-dasar Manajemen Bank Syariah. Alvabet: Jakarta

Badan Pusat Statistik (BPS)

Bank Indonesia. 2009. Hasil Kajian Kredit Konsumsi Mikro, Kecil, dan Menengah untuk Kegiatan Produktif. Direktorat Kredit, BPR, dan UMKM: Jakarta

Bank Indonesia. 2015. Profil Bisnis Usaha Mikro, Kecil, dan Menengah. Direktorat Kredit, BPR, dan UMKM: Jakarta

Bank Indonesia. 2016. Perkembangan Baki Debet Kredit Usaha Mikro, Usaha Kecil, dan Usaha Menengah (UMKM) Perbankan. Departemen Pengembangan UMKM - DPUM: Jakarta

Djuarni, Wenny. 2011. Analisis Perbandingan Metode Pemberian Kredit di Bank Konvensional dengan Pembiayaan Musyarakah di Bank Syariah pada PT. Bank Jabar Banten dan PT. Bank Jabar Syariah . Jurnal Sosial Ekonomi. Jawa Barat

Hariyati, Ninik. 2010. Peran Bank Syariah dalam Mengoptimalkan UMKM Kota Yogyakarta. Tesis. UIN Sunan Kalijaga: Yogyakarta

Haryadi. Profil dan Permasalahan UMKM Provinsi Jambi. Studi Potensi dan Pembinaan UMKM di Provinsi Jambi

Ika Rahmawati, Dewi dan Sambhara kreshna Yudhanta. 2009. Kesesuaian Perlakuan Akuntansi Pembiayaan Syariah dengan Standar Akuntansi Keuangan dan Islamic Values (Studi Kasus Bank Syariah Mandiri Cabang Pamekasan). Jurnal Investasi Vol. 5, No. 1, Juni 2009. Hal. 32-44

Jurana dan Rahman, Arif. 2014. Pengaruh Kualitas Pembiayaan dan dan Kualitas Sumber Daya Manusia Terhadap Efektivitas Pendapatan pada PT. Bank Muamalat Indonesia Tbk Cabang Palu. Jurnal Ilmiah Akuntansi dan Humanika JINAH Volume 3 Nomor 2 Singaraja Juni 2014. ISSN 2089-3310

Sucherly. 2003. Peran Manajemen Pemasaran Stratejik dalam Menciptakan Keunggulan Posisional serta Implikasinya terhadap Kinerja Organisasi Bisnis dan Non Bisnis (Pendekatan 5-A). Orasi Ilmiah. Universitas Padjajaran: Bandung Undang-undang No 20 Tahun 2008 tentang Usaha Mikro, Kecil, dan Menengah 